\title{
Development of E-module Space Geometry Based on Vee's Heuristic Strategy to Train Students' Mathematical Representation Skills
}

\author{
1,2*Aidah Murdikah, ${ }^{2}$ Syamsuri, ${ }^{2}$ Hepsi Nindiasari, ${ }^{2}$ Novaliyosi \\ ${ }^{1}$ SMA Terpadu Al-Qudwah, Jl. Maulana Hasanudin, Banten 42317, Indonesia \\ ${ }^{2}$ Universitas Sultan Ageng Tirtayasa, J1. Raya Jakarta KM. 04 Pakupatan, Serang, Indonesia \\ 42124 \\ *Corresponding Author e-mail: aidahmurdikah7@gmail.com
}

Received: October 2021; Revised: November 2021; Published: December 2021

\begin{abstract}
The research aims to produce e-modules based on vee heuristic strategies that are valid, practical, and effective to train the mathematical representation skills of high school students, with the material used is the geometry of space. This research is development research with 4-D design (Define, Design, Development, and Dissemination). The subjects of this study were students of class XII MIPA and IPS Of Al-Qudwah Integrated High School, which amounted to 30 students. The data in this study was collected using questionnaires and tests. From the analysis results obtained, the average total validation score (RTV) from media experts is 4,062 with an excellent category, material experts with 4,625 with unique varieties, and the average e-module user response score of 89.00 . The indicates that the student's response to Learning using e-modules based on heuristic vee strategies is positive so that e-modules can be declared practical. The mathematical representation of students after using this vee heuristic strategy-based e-module earns a total average of 3.32 with excellent category. Based on the results of such data analysis, the e-module based on vee heuristic strategies developed is worth using as a practical learning resource to train students' mathematical representation skills on space geometry. The app makes it easy for students to access flexible learning resources anywhere and anytime.
\end{abstract}

Keywords: E-modules; heuristic vee strategies; mathematical representation abilities

How to Cite: Murdikah, A., Syamsuri, S., Nindiasari, H., \& Novaliyosi, N. (2021). Development of E-module Space Geometry Based on Vee's Heuristic Strategy to Train Students' Mathematical Representation Skills. Prisma Sains : Jurnal Pengkajian Ilmu dan Pembelajaran Matematika dan IPA IKIP Mataram, 9(2), 301-315. doi:https://doi.org/10.33394/j-ps.v9i2.4314

https://doi.org/10.33394/j-ps.v9i2.4314

Copyright $\odot$ 2021, Murdikah et al This is an open-access article under the CC-BY License.

\section{INTRODUCTION}

Along with the development of the times and the progress of the world of education, many schools have tried to carry out learning well, namely improving the quality and quality of learners, creating easy and fun Learning, and supporting teacher competence development. Components in learning: teachers, students, and the learning process. The learning process will not become effective if one of these components does not exist. For example, there are only teachers and learning processes in the classroom, then who is learning? Therefore it is pretty clear that the component must exist (Dwirahayu \& Nursida, 2016). From the statement, it is also necessary to review from the teacher's side to improve the quality of Learning. From several sources that discuss the competence of teachers, there are several competencies, one of which is the need for teaching skills in implementing and developing each learning process so that teachers can realize and create appropriate Learning for their students. A fun learning process can bring learners to like learning itself. (Dudung, 2018).

The learning process in schools dramatically affects the development of potential learners, as stated in Law No. 20 of 2003 Article 3. According to Permendikbud number 21 
of 2016 on Standards of Content of Mathematics, Subjects for all levels of primary and secondary education must state that mathematics is one of the most critical parts of the field of science. Students must be actively involved in learning to build their knowledge. Through Learning, mathematics does expect to form human resources that can reason logically, critically, systematically, rationally, and carefully. Factors that can support the success of the mathematical learning process are the selection of teaching materials and appropriate learning methods.

The Learning carried out is also considered very inefficient due to students who have done by networking through social media. There is no direct interaction between teachers, students, and their friends in the learning process. The results of interviews with students at SMAT Al-Qudwah found that in learning mathematics, many students complained of lagging the learning material and could not work on the problems given by the teacher. Because the books and teaching materials provided by the school have not supported the online learning process at this time, and at this time, the existing teachers only rely on package books provided by the school to be the only teaching materials used. The entire learning process refers entirely to the package book. But the package book has some drawbacks. Based on the results of previous research, in the material section, students have an excellent opportunity to reason and prove through reading justification but have a slight chance through the development of explanation. In evaluation, students do not have the chance to claim and confirm the quality of the problem with indicators evaluating arguments. The indicates that textbooks have not fully provided students with the chance to learn to reason and prove (Utari \& Hartono, 2019).

Based on the problems described, it does expect that there is one teaching material that can help teachers and students in the learning process in the current pandemic period, to the characteristics of students, essential competencies, and indicators of expected achievement after the learning process (Susilo et al., 2016). Teaching materials that do consider to help learners and teachers in the learning process in the covid pandemic at this time is a module.

According to the Directorate General of Education Quality Development and Education Personnel (2008: 3), modules printed teaching materials designed to be studied independently by learning participants. Modules are also called media for self-study because it has equipped with instructions for self-study. That is, readers can do learning activities without the presence of teachers directly. The language, pattern, other completeness in this module arrange so that it is as if it is the teacher's language or the language of the teacher who is teaching to his students. Therefore this medium is often called self-instructional material. The teacher does not directly teach lessons or teach his students face-to-face, but simply with the modules developed. (Susilo et al., 2016). There are various modules, namely modules in print and non-printing form, modules in the form of non-printing, one of which is an electronic module. According to Doni Sugianto et al., electronic modules can be implemented as independent teaching materials to help students actively participate in the learning process (Solehah, 2015).

The research develops e-modules based on vee heuristic strategies. Because the vee strategy, known as the vee diagram, is a learning strategy that helps students integrate previously learned concepts. At the beginning of the process, students are asked to think about a material (thinking) and then given a problem (problem) that must be solved using previously acquired knowledge. The problem solves in a process called doping. Students obtain a record of the situation observed and get facts based on previously studied theories. Then students receive data represented through tables, diagrams, or graphs. Heuristic vee emphasizes meaningful Learning because it has conceptual coherence and methodology. Conceptual change changes from theory, principle, and concept to a record of transformation and a claim of knowledge connected by events. This strategy can help students build mathematical representation skills (Putra et al., 2018). 
Previous research shows that understanding students' mathematical concepts using heuristic learning strategies are higher than teaching with conventional learning strategies. The average score of the test results of understanding the mathematical concepts of students who use heuristic vee learning strategies is 83.96, while students who use conventional learning strategies are 78.3 (Suhyanto \& Musyrifah, 2016). To understand mathematical concepts and be able to communicate mathematical ideas, students need the ability of mathematical representation in it, in connection with the research of Rahmadian et al., which states that the knowledge of mathematical models is required by students to understand mathematical concepts and to communicate mathematical ideas (Rahmadian et al., 2019). Based on research from (Nelson et al., 2016) and principles and standards for school mathematics (NCTM) in 2000, students must own five means of the mathematical learning process. These mathematical skills must do possessed by students, namely problem-solving skills, communication skills, connection skills, reasoning skills, and representation skills. Mathematical representation is very instrumental because the model aims to make it easier for students to solve mathematical problems that are abstract to be more concrete for students. So on that basis, in addition to developing e-modules based on vee heuristic strategies, the e-module will also include indicators of mathematical repression ability as an ability that do facilitate in this e-module.

Until now, they encountered difficulties in students learning the concept of space geometry. From the interview of researchers with the teacher of mathematics at SMAT AlQudwah Rangkasbitung, it knows that it turns out that most students find it challenging to represent one concept to another in the geometry material of space. Because students still find it challenging to understand the idea of building the space itself. Even though building space is the basis for learning space geometry, students will find it challenging to understand the following material. At the same time, geometry is a mathematical material close to real life and other mathematical topics. The various visualizations that exist in the student world are geometric shapes. According to Usiskin (1980), there are three reasons geometry is essential in mathematics. First, associating physical form in the real world with the world of mathematics can only be done with geometry. Second, the shape of visualization of mathematical ideas can raise with geometry. And lastly, geometry becomes an example of the inaction of mathematical systems (Wulan \& Rosidah, 2020). In learning space geometry carried out at SMAT Al-Qudwah, there is no teaching material or e-module that can facilitate understanding concepts. This situation prompted researchers to develop an e-module based on vee heuristic strategies to train students' mathematical representation skills in the subsubject of space geometry.

Based on the background of problems and literature reviews related to space geometry learning, student representation abilities, and vee heuristic strategies, e-modules based on vee heuristic strategies can use as alternatives to training students' mathematical representation skills in mathematical Learning. However, the development of e-modules in math learning is not easy, especially for teachers in Indonesia. Therefore, the study aims to produce e-modules on space geometry-based materials based on a vee heuristic strategy to train students' mathematical representation abilities. The developed e-modules can assist teachers in aligning space geometry materials based on vee heuristic strategies and practicing students' mathematical representation skills.

\section{METHOD}

The research aims to produce e-modules based on vee heuristic strategies that are valid, practical, and effective to train the mathematical representation skills of Al-Qudwah Integrated High School students. Assessment of quality development products must meet three criteria: good, functional, and practical (Safitri et al., 2020). This type of research is development research. This development will use the 4-D development model developed by Thiagarajan (Fitri, 2021). But because of the study's limitations, the stages used are only 3-D, 
namely Define, Design, and Develop. The following are the design stages used, as presented in Figure 1.

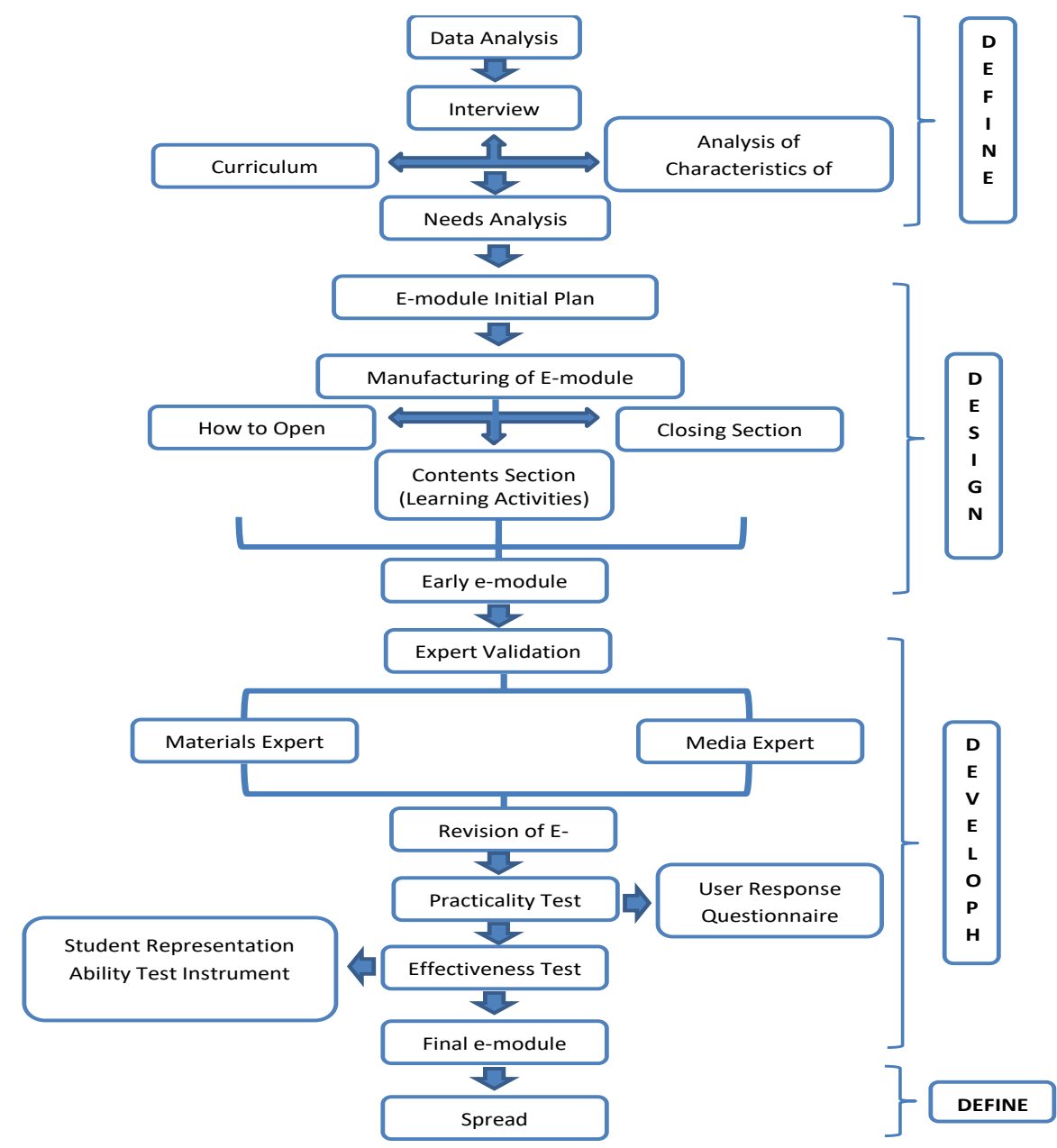

Figure 1. 4-D Learning Device Development Model (Lestari et al., 2019).

Data collection techniques use interviews, expert validation instruments, student response questionnaires, and mathematical representation abilities instructional tests. The data obtained in this study is in the form of quantitative and qualitative data. Quantitative data do obtain from material and media expert validation scores, student response data, and student interest data on developed e-modules. The Qualitative information is from the advice and comments of experts and the results of converting quantitative data to qualitative data.

The instrument used to assess the validity of the e-module is an expert validation sheet. The device used to evaluate practicality is the student's response questionnaire. To determine effectiveness, the instrument used is a test instrument of the student's mathematical representation ability. The data analysis technique used is a quantitative descriptive analysis technique. The data analyzed is data from devices of material expert validation sheets and media experts, student response data, and the ability of mathematical representations of students. Expert trial questionnaires and practicality tests are processed using the Likert scale, while product trial questionnaires or student response questionnaires are processed. The rating scale is based on raw data obtained in numbers and further interpreted qualitatively (Cecep et al., 2019).

Table 1. Rating Scale

\begin{tabular}{lcccccc}
\hline Question form & \multicolumn{3}{c}{ Answers } & & & \\
\cline { 2 - 5 } & Very Good & Good & Enough & Poor & Very Poor \\
\hline Positive questions & 5 & 4 & 3 & 2 & 1 \\
Negative questions & 1 & 2 & 3 & 4 & 5 \\
\hline
\end{tabular}




\section{RESULTS AND DISCUSSION}

The 4-D development stages carried out in this study include defining (definition), design (design), and development (development).

\section{Define}

The define phase has the goal of establishing material restrictions and learning objectives. Activities are carried out in the form of analysis to see obstacles or obstacles that learners have experienced. The definition phase is in 2 ways, namely the study of the godhead and the needs of the concept. At the stage of requirements, analysis by reviewing the applicable curriculum, the implementation of Learning and teaching in schools, and the character of learners. This analysis aims to establish on which competencies the teaching material will be developed. At the concept stage, the study will analyze the fabric combined as content in teaching materials. The activities carried out at this stage look at the syllabus of class XII curriculum 2013, in which there are core competencies (KI) and essential competencies (KD). The material that will do set in this study is the geometry of space. Interview techniques do use to obtain data on the initial analysis in the definition phase. The initial examination consists of curriculum analysis, material analysis, and student characteristics as research subjects.

The definition stage consists of 5 stages, starting with the final initial analysis (frontend analysis), learner analysis, material analysis (concept analysis), task analysis, and learning objective specifications (specifying instructional objectives). From the results of interviews with teachers at SMAT Al-Qudwah, Rangkasbitung and the collection of questionnaires at the final initial analysis stage obtained the following information:

From the final initial analysis stage (front-end analysis), students of class XII MIPA and IPS are less enthusiastic in following the process of learning mathematics, especially in the geometry of space materials. Students feel they cannot understand the concept more deeply. Students find it challenging to change a form of representation to another form of repression, be it in visual conditions, story problems, and make mathematical models. Teaching materials available in school have not fully supported the learning process and teachers still often use lecture methods in delivering the material to be taught.

At the stage of learning analysis, learners (learner analysis) that the mathematical learning process used during school uses the lecture method. So that in the process, students are not actively involved in finding new knowledge independently but through the transfer of knowledge from teacher to student because in the lecture method, students only focus on listening to the teacher's explanation. And also, at this time, the learning media that can support students to be active in every learning activity has not been widely used in school. Based on this, it is necessary to develop teaching materials in e-modules that can be accessed anywhere and stimulate students to be active in classroom learning activities to create efficiency and effectiveness in Learning.

The concept analysis does carry out at this stage by reviewing Core Competencies (KI) and Basic Competencies (KD) following the curriculum listed in Permendikbud Number 37 of 2020. Furthermore, the concept to be developed in this teaching material is the idea of space geometry contained in KD 3.1 Describing the distance in space (between points, points to lines, and points to fields) and 4.1 Determining distances in length (between points, points to bars, and points to areas).

Task analysis at this stage does carry out by identifying and compiling the materials studied systematically by students. The material to be used in this e-module is the geometry material of the room for class XII high school / MAN level. The material organizes into five learning activities.

At the level of learning objectives specifications (specifying instructional objectives), the learning objectives analysis is based on Flat Competence (KD), spelled out at the concept 
analysis stage. The essential complements broke down into several indicators. The material presented follows the learning objectives contained in the e-module.

\section{Design}

At this stage, it aims to design an e-module teaching material product made by researchers. This stage contains the structuring of modules that aim to make it easier for students to learn the material. One module creates to teach one specific material so that students can achieve certain competencies. The writing structure of the module divides into three parts, namely the opening, core, and closing parts.

The first part is the opening part, in this section is the initial stage in the planning of teaching materials that follows the structure of the preparation of the module, namely: 1) The title, the title needs to be exciting and provide an overview of the material to discuss; 2) Preface, contains about the role of modules in the learning process; 3) Table of contents, presenting the topic to be discussed, which sorted by its appearance in the module. In addition, the table of contents should include page numbers, which aims to make it easier for students to find the topics they are looking for; 4) In the information map will be shown the relationship between the issues in the module; 5) The list of competency objectives is the writing of competency objectives that help students to know the knowledge of attitudes or skills that students can master after completing Learning; 6) The initial test aims to find out the student's ability in learning the prerequisite material for studying the material in the module

The second part is the core part, and this section will contain about 1) Introduction or general review of the material serves to provide an overview of the contents of the module, convince students that the material to be studied can be helpful to them, provide information about the material to be studied, associate the material that has study with the material to be studied and provide instructions for studying the material to be presented; 2) Concerning other materials or subjects, the material in the module should be complete meaning all the material that needs to be studied is available in the module; 3) The description of the material is a detailed explanation of the learning material delivered in the module. Organize the content of learning materials in a systematic order and arrangement, making it easier for students to understand. If the material is wide enough, it can develop into several learning activities (KB). Each KB contains a description of the material, assignment, and summary; 4) Assignment, the project's purpose is to affirm the expected competence after studying the module; 5) Summary is the part in the module that examines the main things in the module that has discussed. The summary emphasizes at the end of the module.

The third part is at once the last part that is the closing part, in this closing section contains about: 1) Glossary or a list of terms containing definitions of concept definitions discussed in the module. The definition makes it concise to recall the concepts that have study; 2) The final test is an exercise that students can do after studying 1 part in the module. Students can work on general rules for such final examinations within about $20 \%$ of the time of checking the module; 3 ) The index contains essential terms in the module and the page on which the word do found.

\section{Develop}

\section{E-module Teaching Materials Manufacturing Phase}

In this phase, the creation of e-modules adapts from the structure of the module making, namely the opening, core, and closing (Solehah, 2015). The opening section generated titles, prefaces, table of contents, information maps, competency goals list, and initial tests. 

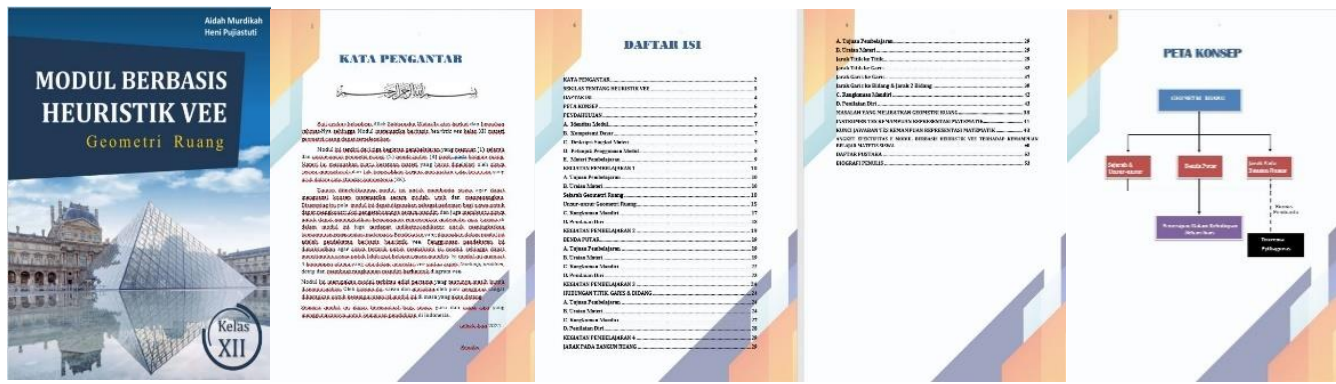

Figure 2. Parts of the opening section

After the opening part procedure, the core part of the module make. The core part emodule make according to the parts that have does determine at the design stage (design) with several parts. The first part, the preliminary or review material, also explains the instructions for using modules in this introduction section. Because the module designed adapts the aspects of the heuristic vee strategy, the opening also defines the three aspects of the steps of the heuristic vee strategy. The second is the association with other materials or lessons, and this section briefly describes the materials discussed in this module. For example, students ask to observe the images available as perceptions at the beginning of the module. The next part made the description of the material. The report of the material produced in this module contains the aspect of thinking. In this aspect, the student will invite to answer questions to associate the concepts that the student has previously had with the new ideas he will learn. It is this aspect that will help students in the process of constructing new knowledge. So that the knowledge gained will be permanent because it forms independently. The fourth part is the assignment process. Based on the heuristic vee strategy in this module, the assignment is in the problem aspect and solved in the doing aspect. Aspect problems contain problems that give after students understand the concept of thinking aspects, and students will solve problems in the aspect of doing. The last part in this core part is the summary. The researcher does not give the overview directly in this module, but the summary made by students who use this module. Because in the heuristic vee strategy adapted by this module and students working on the given problem. In the end, students ask to make a self-contained summary in the form of vee diagrams as products produced by students. And it also serves to affirm the concepts that students have understood in terms of Learning.

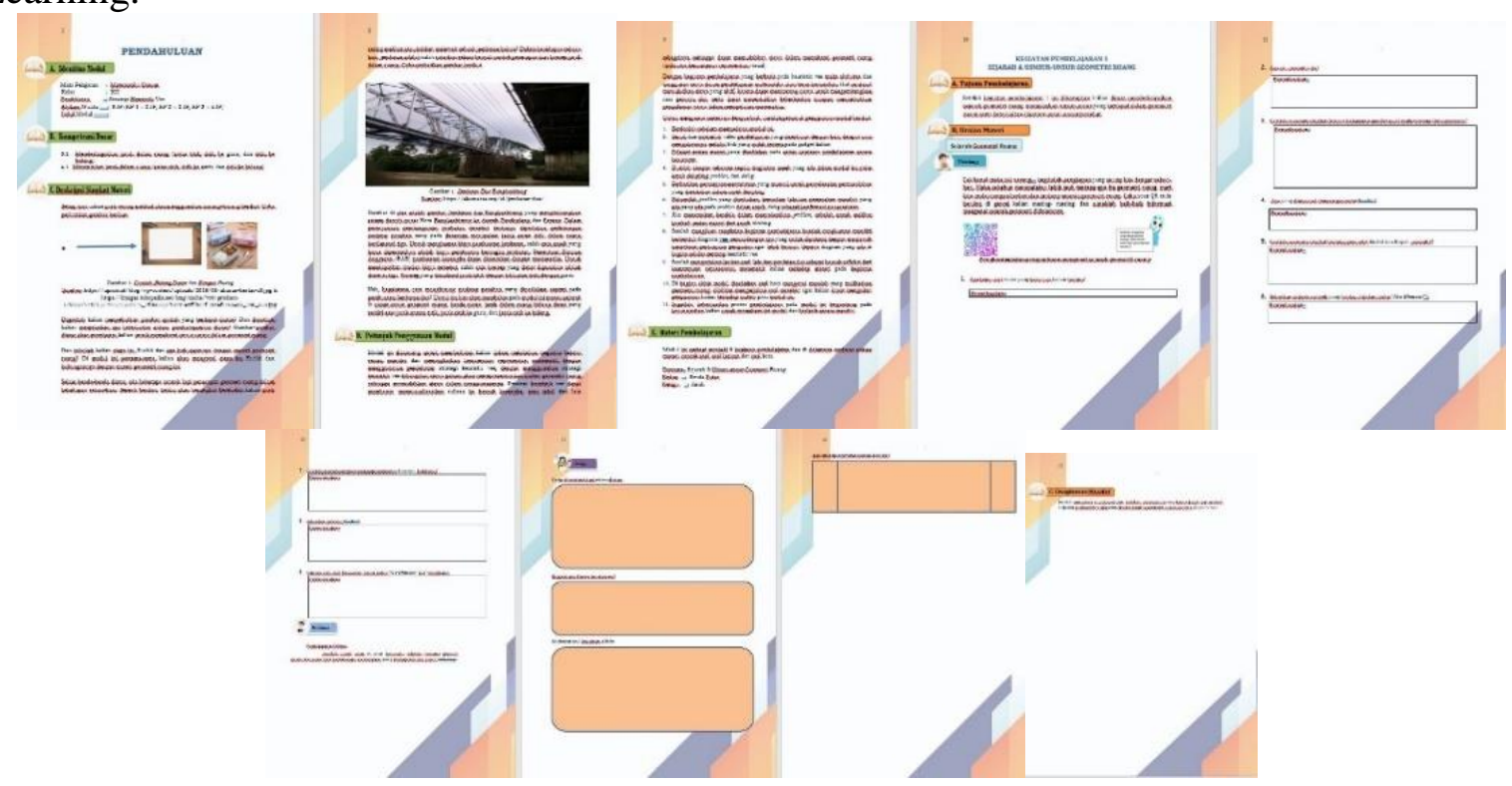

Figure 3. Parts of the core

The last part is like the closing. This section contains the glossary, index, and also final test. In this module, all learning activities and using heuristic vee strategies also apply 
mathematical representation skills. The final test contained in this module includes instrument tests of mathematical representation ability. It aims to find out the effectiveness of this module in training the knowledge of mathematical representation students. In addition to the instrument test knowledge mathematical expression of students in the closing of this module, there is also an effective e-module questionnaire. This questionnaire aims to find out the effectiveness of this e-module for students.
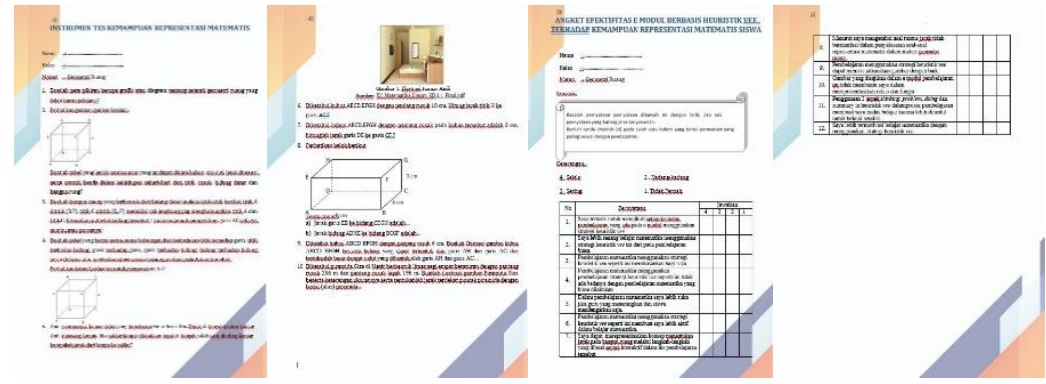

Figure 4. Parts of the cover

The result of this entire draft is further named current I.

\section{Assessment Phase}

At this stage, it dived into 3, namely validation, revision, and limited testing.

Validation of E-Modules

With expert trials after the e-module do compile. Validators who assess e-modules consist of two experts, namely material experts by two validators ( 2 math teachers) and validation instruments of teaching materials or media by two validators ( 2 experts from mathematics education) to validate in terms of materials and media. Advice from experts will use as reference material for the revision of e-modules.

Expert validation techniques do use to assess the validity of e-modules by experts. The e-module validity data developed is based on assessments from media experts and material experts. There are two media experts and two content experts who assess the product. The first and second media experts work as lecturers at Sultan Ageng Tirtayasa State University with expertise in mathematical learning media. The foremost material expert worked as a teacher at Al-Qudwah Integrated High School with expertise in mathematics learning. The second material expert works as a math teacher and deputy principal at SMKN 6 Tangerang with education and mathematics curriculum expertise. The media expert validation sheet and the material consist of 7 and 7 statements, respectively. The scale used is the Likert scale consists of five choices, namely Very Good (score 5), Good (score 4), Enough (score 3), Less (score 2), and Very Less (score 1). Table 2 and 3 aspects and indicators on validated instruments (Safitri et al., 2020).

Table 2. Aspects of validity assessed by material experts (Safitri et al., 2020)

\begin{tabular}{ll}
\hline Aspects & Indicator \\
\hline Conformity & $\begin{array}{c}\text { Conformity of learning media with learning competencies and student } \\
\text { development level }\end{array}$ \\
Facilities & $\begin{array}{l}\text { An easy-to-understand language and an easy-to-use learning medium for } \\
\text { students }\end{array}$ \\
Completeness & $\begin{array}{l}\text { Completeness of materials and training of questions contained in the e- } \\
\text { module }\end{array}$ \\
Clarity & $\begin{array}{l}\text { Clarity of material description, illustration, and provision of problems } \\
\text { and systematic material arrangements in the learning media }\end{array}$ \\
\hline
\end{tabular}

Table 3. Aspects of validity assessed by media experts (Safitri et al., 2020)

Aspects Indicator


Conformity

Ease

Display

Communicative
Accuracy in the selection of learning media based on learning objectives and characteristics of learners, as well as accuracy in the selection of material content, illustrations, and images

Easy to use by teachers and students

The Learning and illustrations, as well as clear and neat layouts.

An easy-to-understand language and an easy-to-use learning medium for students

Next is the revision stage, after validation, and experts give revisions. So the researcher revises by the advice given by the experts, proof continues until the e-module is declared fit for use by experts. In the analysis of expert validation sheets, there are steps taken, namely: calculating the average total score of each aspect, calculating the average total validation score (RTV) for all experts, and converting RTV into qualitative categories concerning categorization guidelines according to (Safitri et al., 2020). The e-module validity criteria in this study are if the type of validity is of a minimum valid value. The kinds of facts in this study do present in Table 4

Table 4. E-module validan category (Safitri et al., 2020)

\begin{tabular}{ll}
\hline Score interval & Category of validan \\
\hline $4,01<R \mathrm{TV} \leq 5,00$ & Higly Valid \\
$3,34<R \mathrm{TV} \leq 4,01$ & Valid \\
$2,67<R \mathrm{TV} \leq 3,34$ & Enough Valid \\
$2,00<R \mathrm{TV} \leq 2,67$ & Valid Less \\
$1,00<R \mathrm{TV} \leq 2,00$ & Not Valid \\
\hline
\end{tabular}

\section{Practicality of E-modules}

After the e-module is declared valid and suitable for use by experts, the next stage is to test 15 students of class XII MIPA and 15 students of class XII IPS at Al-Qudwah Integrated High School, Rangkasbitung, to see the student response to the e-module. The selection of research subjects does base on students who have obtained space geometry materials in math lessons. Learners' response questionnaire techniques use to get responses to assess the practicality of the e-module. On the practicality instrument, the student response questionnaire contains 15 positive statements. For each information, there are five options, namely Very Good (score 5), Good (score 4), Enough (score 3), Less (score 2), and Very Less (score 1). Students ask to choose one option according to how they felt based on the statements in each item. Statement items on the student response questionnaire are present in Table 5.

Table 5. Statement item on student response questionnaire (Safitri et al., 2020)

\begin{tabular}{ll}
\hline Aspects & Indicator \\
\hline Quality of content & Material is easy to understand \\
& The view on the e-module is clear \\
& The learning path is clear and easy to understand \\
Pleasure & There is a sense of pleasure during the learning process \\
& E-module displayed looks new \\
& The e-module shown looks attractive \\
& E-modules used to foster student learning motivation \\
Grammar & Languages used in e-modules that are easy to understand \\
Use of illustrations & Images and illustrations displayed by the material \\
& Pictures and descriptions show clearly and neatly \\
& Use of colors that match the characteristics of students \\
& Representatives are used to making students better understand formulas \\
& or materials
\end{tabular}


The student response questionnaires do conduct by calculating the average total score. Suppose the average score obtained from the student's response to learning using e-modules is more than or equal to 70 . In that case, the student response is positive, and the e-module is otherwise practical.

\section{Effectiveness of E-modules}

The final stage in this assessment is to share the mathematical representation ability test instrument used to measure the student's mathematical representation ability. While The results use to see the effectiveness of the e-module developed. The mathematical representation ability test instrument does use to measure the power of a student's mathematical representation. The results use to see the effectiveness of the e-module developed. On effectiveness instruments, the instrument sheet tests the ability of mathematical models to be given to students before and after using the e-module learning medium so that changes in the student's mathematical representation of the e-module can develop. On the questionnaire sheet, the ability of mathematical model of students there is nine questions. Each answer contains the suspension guidelines contained in the module. The scores will be recapitulated and calculated to get the total average. Aspects and indicators of students' mathematical representation abilities are present in Table 6.

Table 6. Aspects and indicators of Student Mathematical Representation (Murdikah, 2016)

\begin{tabular}{ll}
\hline Aspects & Indicator \\
\hline Visual & Can represent data or information from a representation to a \\
& representation of diagrams or graphs, as well as tables on the \\
& history of space geometry and elements of space geometry \\
& Can make rotary images of words or expressions given \\
& Mathematics
\end{tabular}

Mathematical

Equations/Expressions

Words or text

Written

Equations/Expressions

Mathematics \& Word

written word or text

Visuals \&

Equations/Expressions

Mathematical
Expresses a distance with a mathematical model or expression

Mathematical.

Writing down mathematical problem-solving steps is determining the distance in building space with written words or text

Can solve a problem from a visual representation in the form of images into mathematical models or expressions, and can Write down the steps with written words or text.

Create an illustration of a visual representation of an image of an problem-solving involving the geometry of space and can expresses a distance from a mathematical model or expression Mathematical

The analysis of instrument data tests the ability of mathematical representations of students obtained before and after using e-modules. It does so by calculating the average score. Then from the average total received, the effectiveness category. There are four categories of effectiveness, as shown in Table 7. Teaching materials do consider adequate if students' average total mathematical representation ability after Learning is at least at intervals of 2.00 $<\mathrm{x} \overline{\mathrm{x}} \leq 3.00$ with good categories.

Table 7. Effectiveness category based on total average (Safitri et al., 2020)

\begin{tabular}{ll}
\hline Interval score & Category effectiveness \\
\hline $3,00<x \bar{x} \leq 4,00$ & Excellent \\
$2,00<x \bar{x} \leq 3,00$ & Good \\
$1,00<x \bar{x} \leq 2,00$ & Less Good \\
$x \leq 1,00$ & Not Good \\
\hline
\end{tabular}


Categories of improving the ability of mathematical representations of students before and after using e-modules do calculate using the N-gain formula. Gain score (g) compares the ability score of a mathematical model of students before and after learning. Here is an equation to calculate the gain of each student.

$$
(g)=\frac{\text { Posttest Score }- \text { Pretest Score }}{\text { Maximum Score }- \text { Pretest Score }}
$$

Furthermore, the average value of gain gained categorized as in Table 8 (Murdikah, 2016)

Table 8. Interpretation of gain value

\begin{tabular}{cl}
\hline Range of values $\mathrm{g}$ & Classification \\
\hline $0,7 \leq \mathrm{g}$ & High \\
$0,3 \leq \mathrm{g}<0,7$ & Medium \\
$\mathrm{g}<0,3$ & Low \\
\hline
\end{tabular}

Here is an explanation of the results of the tests that have does done:

\section{E-Module Validation Results}

In this phase, the results of assessments from media expert validators and material experts are present in Table 9 and Table 10.

Table 9. Validation results by media experts

\begin{tabular}{lcccl}
\hline Assessment Aspects & Validator 1 & Validator 2 & Average & Information \\
\hline Conformity & 4,00 & 4,00 & 0,00 & Highly Valid \\
Ease & 4,00 & 5,00 & 0,00 & Highly Valid \\
Display & 4,00 & 3,5 & 0,00 & Highly Valid \\
Communicative & 4,00 & 4,00 & 0,00 & Highly Valid \\
Average total validation (RTV) & & 4,062 & Highly Valid \\
\hline
\end{tabular}

Tabel 10. Validation results by material experts

\begin{tabular}{lcccl}
\hline Assessment Aspects & Validator 3 & Validator 4 & Average & Information \\
\hline Conformity & 5,00 & 5,00 & 5,00 & Highly Valid \\
Facilities & 4,50 & 5,00 & 4,75 & Highly Valid \\
Completeness & 4,00 & 5,00 & 4,50 & Highly Valid \\
Clarity & 4,50 & 4,00 & 4,25 & Highly Valid \\
\hline Average total validation (RTV) & & 4,625 & Highly Valid \\
\hline
\end{tabular}

Table 9 and Table 10 show that the e-module received a valid assessment from media validators and material experts. While in terms of material, e-modules have also fulfilled aspects of conformity with learning competencies and student development levels; aspects of earthly completeness and training of questions contained in teaching materials; aspects of convenience to be understood and used by students; as well as aspects of Clarity in displaying material descriptions, illustrations, and problem-giving and systematic arrangement of material in e-modules.

\section{E-module Practicality Assessment Results}

The results of the e-module practicality assessment do obtain from the trial activities. Students were given questionnaires regarding their responses after learning e-modules based on vee heuristic strategies in the trial activity. Student response data results to e-module do show in Table 11. 
Table 11. Student response data results to e-modules

\begin{tabular}{|c|c|c|c|c|c|c|}
\hline & & \multicolumn{4}{|c|}{ Response } & \multirow{2}{*}{$\begin{array}{l}\text { Average score } \\
\text { Total }\end{array}$} \\
\hline & & $\mathrm{K}(2)$ & C (3) & B (4) & SB (5) & \\
\hline $\begin{array}{l}\text { Average } \\
\text { response }\end{array}$ & score & 0.00 & 5.00 & 45.00 & 50.00 & 89.00 \\
\hline
\end{tabular}

Table 11 shows that the average response on Verry Good (SB) and Good (B) options is higher compared to Options Enough (C) and Less (K). Indicates that the student agrees or strongly agrees with positive statements regarding the e-module. The total response score average also showed 89, meaning most students respond positively to e-modules on vee heuristic-based space geometry materials. That indicates that the student's response to Learning using e-modules is positive so that e-modules can be declared practical.

E-module Effectiveness Results

Data on students' mathematical representation abilities do use to assess the effectiveness of animated films. Data on students' mathematical representation abilities do obtain from trial activities. Students fill out tests of students' mathematical representation skills before and after learning. An increase in students' learning interest can show before and after learning using e-modules. The results of the data analysis of students' mathematical representation ability before and after learning using e-modules does present in Table 12 and Table 13.

Table 12. Data on students' mathematical representation abilities before learning

\begin{tabular}{|c|c|c|c|c|c|c|c|c|c|c|}
\hline & \multicolumn{10}{|c|}{ Question points } \\
\hline & 1 & 2 & 3 & 4 & 5 & 6 & 7 & 8 & 9 & 10 \\
\hline Average per item & 4.00 & 4.00 & 2.23 & 2.25 & 3.37 & 2.37 & 2.20 & 1.69 & 2.75 & 2.88 \\
\hline Total average & 2.77 & & & & & & & & & \\
\hline \multicolumn{11}{|c|}{ Table 13. Data on students' mathematical representation abilities after learning } \\
\hline & \multicolumn{10}{|c|}{ Question items } \\
\hline & 1 & 2 & 3 & 4 & 5 & 6 & 7 & 8 & 9 & 10 \\
\hline Average per item & 4.00 & 4.00 & 3.09 & 3.15 & 3.65 & 3.08 & 3.00 & 2.63 & 3.20 & 3.45 \\
\hline Total average & 3,32 & & & & & & & & & \\
\hline
\end{tabular}

Table 12 and Table 13 show that the average in each statement item after Learning has a positive increase from the norm in each statement item before learning. The total standard after knowledge is higher than the total average before expertise. It indicates that students' ability to mathematical representation after learning increases compared to before learning using e-modules. Table 13 shows that the average total mathematical representation ability of students is 3.32. Based on Table 6, the total average of 3.32 falls in the 'Excellent' effectiveness category. Thus, the e-modules developed does effectively reviewed the ability of the student's mathematical representation.

Table 14. N-gain calculation results

\begin{tabular}{ll}
\hline Parameter & Score \\
\hline Maximum Score & 4.00 \\
The average score pretest & 2.77 \\
Averagescore posttest & 3.32 \\
Gain $(g)$ & 0.45 \\
\hline
\end{tabular}

Table 14 shows that the gain value increases the student's mathematical representation ability before and after learning using e-module teaching materials is 0.45 . Based on the interpretation of the gain value in Table 7 , the increase falls into the moderate category. It showed that although students' mathematical representation ability increased, the increase 
was not so significant. Researchers pay less attention to other factors that affect students' mathematical representation ability. Among them is the lack of basic understanding and knowledge related to the matter, subjects who cannot present problems in patterns. In answering the subject question using mathematical representations that are not precise, the subject cannot manipulate existing practices, and the issue feels he has no expertise in drawing. The matter has difficulty pouring what he understands in writing (Amaliyah AR \& Mahmud, 2018).

E-modules on sub-geometry of space based on vee heuristic strategies have been piloted to class XII high school students. The results obtained show that after using emodules based on vee heuristic strategies, the following the opinion of (Cecep et al., 2019), the Quick Math module can use as a learning resource according to the demands of the 2013 curriculum. The app makes it easy for students to access flexible learning resources anywhere and anytime. And also, following opinions (Khairiyah \& Faizah, 2019), the use of integrated thematic modules is effective and can be further implemented and improve students' critical thinking skills.

\section{Discussion}

The results showed that students' responses to the e-modules were also positive. The emodules used in Learning and the content of e-modules integrated with aspects contained in vee heuristic strategies are new to students. Thus, e-modules that combine mathematics with learning strategies or theories, such as heuristic vee, problem-based Learning, and others, respond positively. Research from (Khairiyah \& Faizah, 2019) shows that learning mathematics using Islamic integration modules can improve students' critical thinking skills and positively respond.

Based on results showing that students' mathematical representation skills improve after using e-modules, this developed medium can be used as an alternative for teachers to apply varied and innovative Learning. Not only for face-to-face Learning, but e-modules can also use for online learning and train students' independence in Learning (Huwana, 2020). Can make online Learning during this pandemic can be more attractive to students in education. A good interest in Learning will also increase good mathematical problem-solving skills (Islahiyah et al., 2021).

This e-module can also use as an alternative in facilitating the construction of new knowledge independently in students. The knowledge possessed by students can last longer because it obtains from the results of self-construction and self-understanding. Nevertheless, many teachers feel that Learning using e-module teaching materials will take up a lot of time in the learning process because teachers emphasize closed knowledge and aim only for standardized tests. Not to increase student understanding, expand the scope of student knowledge, or students deepen student knowledge. In fact, according to Utari and Hartono, the supposed part of the material, students have an excellent opportunity to reason and prove through reading justification, but because teachers only use existing printed books so that students have a slight chance through the development of explanation. In evaluation, students do not have the opportunity to reason and prove through the quality of the problem with indicators evaluating arguments. That is, textbooks have not fully provided students with the chance to learn to claim and prove (Utari \& Hartono, 2019). In line with these opinions, this e-module can use to facilitate students to learn to reason and prove.

This research has some limitations. First, the n-gain result increases the ability of mathematical representation of students to fall into the moderate category. This research needs to be examined further about other factors of the knowledge of the mathematical model of students. Nevertheless, the study's findings successfully showed that e-modules influence is practicing the mathematical representation abilities of students. These limitations can use as recommendations for future research that e-modules can use to train students' mathematical representation skills. Still, they must look at other factors that affect mathematical representation ability according to the characteristics and conditions of the 
student's learning environment. The second limitation is that the power of researchers in developing e-modules for deeper space geometry materials is one of the shortcomings of this study. It is because the e-module process has long and long steps. However, if teachers want to develop e-modules that contain complete material, they can work with others to design emodules in Learning. For further research can be developed teaching materials that have learning strategies or other learning theories into other materials in mathematics lessons.

\section{CONCLUSION}

Based on the research, the e-module based on vee heuristic strategies is considered feasible and can use in the learning process based on the assessment of experts, including material experts and media experts. The user response was that students showed excellent responses, with an average response of 89.00. The indicates that the student's response to Learning using e-module based vee heuristic strategies is positive so that e-modules can be declared practical. As for the ability of mathematical representation of students after using emodules based on vee heuristic strategies, this earned a total average of 3.32. Based on Table 6 , the total average of 3.32 falls in the 'Excellent' effectiveness category. Thus, the e-modules developed does effectively reviewed the student's mathematical representational abilities.

\section{RECOMMENDATION}

Based on the research, the e-module based on vee heuristic strategies is considered feasible and can use in the learning process based on the assessment of experts, including material experts and media experts. The user response was that students showed excellent responses, with an average response of 89.00. The indicates that the student's response to Learning using e-module based vee heuristic strategies is positive, so e-modules can be declared practical. As for the ability of mathematical representation of students after using emodules based on vee heuristic strategies, this earned a total average of 3.32. Based on Table 6 , the total average of 3.32 falls in the 'Excellent' effectiveness category. Thus, the e-modules developed effectively reviewed the student's mathematical representational abilities.

\section{ACKNOWLEDGMENTS}

The study did not receive any special grants from any funding agency in the public, commercial, or nonprofit sectors.

\section{REFERENCES}

Amaliyah AR, R., \& Mahmud, N. (2018). Analisis kemampuan representasi matematis dalam pemecahan masalah geometri serta faktor-faktor yang mempengaruhinya. Jurnal Review Pembelajaran Matematika, 3(2), 146-160. https://doi.org/10.15642/jrpm.2018.3.2.146160

Cecep, C., Mutaqin, A., \& Pamungkas, A. S. (2019). Pengembangan modul quick math berbasis mobile learning sebagai penunjang pembelajaran matematika di SMA. Prisma Sains : Jurnal Pengkajian Ilmu Dan Pembelajaran Matematika Dan IPA IKIP Mataram, 7(2), 148. https://doi.org/10.33394/j-ps.v0i0.1761

Dudung, A. (2018). Kompetensi profesional guru. JKKP (Jurnal Kesejahteraan Keluarga Dan Pendidikan), 5(1), 9-19. https://doi.org/10.21009/jkkp.051.02

Dwirahayu, G., \& Nursida. (2016). Mengembangkan pembelajaran matematika dengan menggunakan metode permainan untuk siswa kelas 1 MI. Jurnal Matematika Dan Pendidikan Matematika, 5(2), 117-138.

Fitri, A. (2021). Pengembangan handout berbasis model pembelajaran pembangkit argumen untuk melatih kemampuan berpikir logis matematis. UIN Syarif Hidayatullah.

Huwana, E. (2020). Pengembangan e-modul pembelajaran matematika berbasis pendekatan kontekstual pada siswa kelas VII SMP Negeri 5 Salatiga kecamatan sidomukti kota Salatiga tahun pelajaran 2020/2021. IAIN Salatiga. 
Islahiyah, I., Pujiastuti, H., \& Mutaqin, A. (2021). Analisis kebutuhan e-modul dengan model pembelajaran berbasis masalah pada materi barisan dan deret kelas XI SMA. TIRTAMATH: Jurnal Penelitian Dan Pengajaran Matematika, 3(1), 47. https://doi.org/10.48181/tirtamath.v3i1.11135

Khairiyah, U., \& Faizah, S. N. (2019). The effectiveness of using the islamic integration module on the critical thinking ability of madrasah ibtidaiyah students. Prisma Sains: Jurnal Pengkajian Ilmu Dan Pembelajaran Matematika Dan IPA IKIP Mataram, 7(2), 180. https://doi.org/10.33394/j-ps.v7i2.1780

Lestari, H., Pamungkas, A. S., \& Alamsyah, T. P. (2019). Pengembangan lembar kerja siswa eksploratif berkonteks budaya banten pada mata pelajaran natematika di sekolah dasar. Prisma Sains : Jurnal Pengkajian Ilmu Dan Pembelajaran Matematika Dan IPA IKIP Mataram, 7(1), 48. https://doi.org/10.33394/j-ps.v0i0.1401

Murdikah, A. (2016). Pengaruh strategi heuristik vee terhadap kemampuan representasi matematis siswa. Universitas Muhammadiyah Tangerang.

Nelson, G., Jitendra, A. K., Nelson, G., Pulles, S. M., Kiss, A. J., \& Houseworth, J. (2016). Is a mathematical representation of problems evidence-based? Is a mathematical model of the issues an evidence-based strategy for students with mathematics difficulties? Exceptional Children, 83 (1)(August 2018). https://doi.org/10.1177/0014402915625062

Putra, L. V., Purwanti, K. Y., \& Khoiriyah, I. S. A. (2018). Pembelajaran Matematika Model Tutor Sebaya Dengan Strategi Heuristik VEE. JANACITTA: Journal of Primary and Children's Education, 1(2), 2615-6598. http://jurnal.unw.ac.id/index.php/janacitta

Rahmadian, N., Mulyono, \& Isnarto. (2019). Kemampuan representasi matematis dalam model pembelajaran somatic, auditory, visualization, intellectually (SAVI). PRISMA, Prosiding Seminar Nasional Matematika, 2, 287-292. https://journal.unnes.ac.id/sju/index.php/prisma/article/view/28940

Safitri, W. Y., Retnawati, H., \& Rofiki, I. (2020). Pengembangan film animasi aritmetika sosial berbasis ekonomi syariah untuk meningkatkan minat belajar siswa MTs. Jurnal Riset Pendidikan Matematika, 7(2), 195-209.

Solehah, E. E. H. (2015). Pengaruh e-module berbasis contextual teaching and learning ( CTL ) terhadap hasil belajar siswa pada konsep fluida statis. UIN Syarif Hidayatullah.

Suhyanto, O., \& Musyrifah, E. (2016). Pengaruh strategi heuristik vee terhadap kemampuan pemahaman konsep matematik. FIBONACCI Jurnal Pendidikan Matematika \& Matematika, 2, 40-57.

Susilo, A., Siswandari, \& Bandi. (2016). Pengembangan modul berbasis pembelajaran saintifik untuk peningkatan kemampuan mencipta siswa dalam proses pembelajaran akuntansi siswa kelas XII SMAN 1 Slogohimo 2014. Jurnal Pendidikan Ilmu Sosial, 26(1), 50-56.

Utari, T., \& Hartono, H. (2019). Muatan penalaran dan pembuktian matematis pada buku teks matematika SMA kelas X Kurikulum 2013. Jurnal Riset Pendidikan Matematika, 6(1), $1-13$.

Wulan, E. R., \& Rosidah, N. I. (2020). Bagaimana problem solving geometri ruang dari level berpikir van hiele siswa? Lentera Sriwijaya: Jurnal Ilmiah Pendidikan Matematika, 2(1), 22-40. https://doi.org/10.36706/jls.v2i1.11442 